\author{
Justyna Dudek \\ (Instytut Pamięci Narodowej Oddział w Lublinie)
}

\title{
Delegatura Sił Zbrojnych oraz I Zarząd Główny WiN wobec porozumienia z OUN-UPA na Lubelszczyźnie ${ }^{1}$
}

\author{
The attitude of the leadership of the Delegacy of Armed Forces at Home \\ and the "Freedom and Independence" towards an agreement \\ between DSZ/WiN and OUN-UPA in the Lublin Region
}

\section{STRESZCZENIE:}

Artykuł porusza problem stosunku kierownictwa Delegatury Sił Zbrojnych oraz I Zarządu Głównego WiN do lokalnego porozumienia zawartego między polskim poakowskim podziemiem a ukraińskim (OUN-B, UPA) podczas spotkania przedstawicieli obu stron, 21 maja 1945 r., w okolicach Rudy Różanieckiej. Bez wątpienia zawarte wówczas zawieszenie broni obejmujące obszar południowo-wschodniej Lubelszczyzny i rozszerzone następnie na teren Podlasia przyczyniło się do zaprzestania trwających od wiosny 1944 r. walk polsko-ukraińskich. Autorka wykorzystując nieznane do tej pory dokumenty pokazuje, że wbrew temu co niejednokrotnie pisali świadkowie tamtych wydarzeń, zostało one zaakceptowane przez kierownictwo DSZ w formie lokalnego paktu o nieagresji. Przywódcy polskiej konspiracji od początku godzili się na zawieszenie broni, choć jednocześnie nie chcieli zawierania umów i nie widzieli możliwości bliższej współpracy i współdziałania z OUN-UPA czy reprezentowania sprawy ukraińskiej na forum międzynarodowym. Powstanie zaś Zrzeszenia Wolność i Niezawisłość, które proponowało cywilny model konspiracji i odcinało się od zwierzchnictwa Rządu na Uchodźstwie, przyczyniło się do tego, że strona ukraińska jak i polska były coraz mniej zainteresowane współpracą.

Słowa kluczowe: Delegatura Sił Zbrojnych, Zrzeszenie Wolność i Niezawisłość, polsko-ukraińskie porozumienie, Lubelszczyzna, proces I ZG WiN

Problematykę kontaktów przedstawicieli lubelskiej konspiracji Delegatury Sił Zbrojnych oraz Zrzeszenia Wolność i Niezawisłość z wysłan-

1* Artykuł jest fragmentem przygotowywanej do druku przez autorkę biografii Mariana Gołębiewskiego. 
nikami Ukraińskiej Głównej Rady Wyzwoleńczej (UHWR), członkami Organizacji Ukraińskich Nacjonalistów - Bandery i Ukraińskiej Powstańczej Armii, których efektem było zawarcie 21 maja 1945 r. lokalnego porozumienia, historycy podejmowali już kilkakrotnie w swoich badaniach ${ }^{2}$. Jednym z omawianych wątków był stosunek, jaki kierownictwo DSZ, a później I Zarządu Głównego WiN zajęło wobec inicjatywy zapoczątkowanej przez lokalnych dowódców poakowskiej konspiracji. Pierwsi, którzy ten temat podjęli, tj. Antoni Szcześniak i Wiesław Szota, pisali, że nie dysponujemy materiałem pozwalajacym na określenie stanowiska Komendy Głównej DSZ i WiN w sprawie problemów wspótpracy z OUN-UPA ${ }^{3}$. Po latach okazuje się, że nie jest do końca tak, jak dowodzili tego wspomniani autorzy. Co prawda materiał archiwalny, który posiadamy, pochodzi ze śledztwa i procesu I ZG WiN oraz składają się na niego wspomnienia tudzież relacje uczestników tej rozprawy. W poniższym tekście chciałabym bliżej przyjrzeć się tej kwestii, wykorzystując oprócz wskazanych źródeł także przechowywane w Bibliotece Uniwersytetu Warszawskiego dokumenty z zespołu Biura Informacji i Propagandy KG AK, gdyż rzucają one nieco więcej światła w szczególności na stosunek do kwestii lokalnego porozumienia Delegatury Sił Zbrojnych. Celem artykułu jest zatem ukazanie stanowiska DSZ oraz I ZG WiN wobec rozmów polsko-ukraińskich na Lubelszczyźnie.

Krwawe polsko-ukraińskie walki z wiosny i lata 1944 r. zaogniły i tak bardzo napięte $\mathrm{w}$ okresie niemieckiej okupacji stosunki między obu narodowościami zamieszkującymi Lubelszczyznę. Przerwało je dopiero wkroczenie w lipcu 1944 r. Armii Czerwonej. Nieformalne strefy wpływów, które ukształtowały się w wyniku owych wiosenno-letnich walk, obowiązywały także po lipcu 1944 r., a ich naruszenie kończyło się krwawo

${ }^{2}$ Na ten temat pisali m. in.: A. B. Szcześniak, W. Z. Szota, Droga donikąd. Działalność organizacji Ukraińskich nacjonalistów i jej likwidacja w Polsce, Warszawa 1973, s. 327-352; R. Wnuk, Konspiracja akowska i poakowska na Zamojszczyźnie od lipca 1945 do 1956 roku, Lublin 1992, s. 41-45; G. Motyka, R. Wnuk, Pany i rezuny. Wspótpraca AK-WiN i UPA 1945-1947, Warszawa 1997; J. Kopiński, Konspiracja akowska i poakowska na terenie Inspektoratu Rejonowego "Radzyń Podlaski” w latach 1944-1956, Biała Podlaska 1998, s. 57-63; G. Motyka, Tak było w Bieszczadach. Walki polsko-ukraińskie 1943-1948, Warszawa 1999, s. 224-227, 271-274; Ł. Kamiński, Próby porozumienia polskiego i ukraińskiego podziemia w latach 1945-1946. Dokumenty, „Wrocławskie Studia Wschodnie” 1999, nr 3; R. Wnuk, Lubelski Okręg AK, DSZ i WiN 19441947, Warszawa 2000, s. 124-150; M. Zajączkowski, Drogi do porozumienia między polskim i ukrainskim podziemiem niepodległościowym w latach 1945-1947 [w:] Od zniewolenia do wolności. Studia historyczne, red, A.F. Baran, Warszawa - Białystok 2009, s. 271-316; M. Moszkowicz, Gdzie w maju 1945 r. kierownictwo Inspektoratu AK-DSZ Zamość prowadziło rozmowy i zawarło porozumienie z OUN-B i UPA?, "Cieszanowskie Zeszyty Regionalne” 2012, z. 5, s. 71-86.

${ }^{3}$ A. B. Szcześniak, W. Z. Szota, op. cit., s. 350. 
zarówno dla jednej, jak i drugiej strony. Wydawało się, że wydarzenia II wojny światowej zbudowały między obydwoma narodami mur nie do przebicia. Wkrótce jednak okazało się, że po jednej i drugiej stronie pojawiła się myśl pokojowego ułożenia wzajemnych relacji, a powodem stało się jednakowe traktowanie przez Sowietów aspiracji niepodległościowych Polaków oraz Ukraińców.

Idea porozumienia dojrzewała jednocześnie po obu stronach, choć niewątpliwie przyświecały im inne motywy. Polskie podziemie poakowskie $\mathrm{w}$ pierwszym rzędzie oczekiwało zaprzestania wyniszczającej walki. Z kolei OUN-B i UPA poszukiwała za pośrednictwem Polaków kanałów łączności z Europą Zachodnią aby w ten sposób móc informować o prowadzonej walce $\mathrm{z}$ władzą sowiecką. Ukraińcy traktowali polskie podziemie jako pas transmisyjny do kontaktów z Zachodem ${ }^{4}$. Widzieli w ten sposób możliwość podniesienia sprawy walki wyzwoleńczej narodu ukraińskiego na arenie międzynarodowej ${ }^{5}$. Zapewne też, jak pisał Mariusz Zajączkowski, w działaniach OUN-B było sporo chłodnej politycznej kalkulacji6.

Zmiana taktyki banderowskiego podziemia wobec Polaków nastąpiła, gdy Sowieci w 1944 r. zajęli zachodnie tereny Ukrainy i wschodnie obszary dzisiejszej Polski. 1 września 1944 r. wydano rozkaz nakazujący wstrzymanie „antypolskiej akcji” w Galicji Wschodniej i szukania możliwości porozumienia z Polakami, wymierzonego w Sowietów ${ }^{7}$. Pomimo tego nadal zdarzały się napady na miejscowości zamieszkane przez Polaków ${ }^{8}$. W lutym 1945 r. wydano kolejne instrukcje, w których mówiło się już o konieczności podjęcia rozmów z polskim podziemiem9. Do szukania takich kontaktów za linią Curzona udał się płk Jurij Łopatyński „Szejka”10. "Szejk" miał za zadanie dobrnać do KG WiN i tam prowadzić rozmowy na temat współpracy - mówił podczas przesłuchania Piotr Fedoriw, szef Służby Bezpeky OUN ${ }^{11}$.

${ }^{4}$ M. Zajączkowski, Działalność Organizacji Ukraińskich Nacjonalistów i Ukraińskiej Powstańczej Armii na Lubelszczyźnie 1939-1947, ISP PAN, (mps rozprawy doktorskiej), s. 464.

${ }^{5}$ Idem, Działalność Organizacji Ukraińskich..., s. 463-464; G. Motyka, Ukraińska partyzantka 1942-1960, Warszawa 2006, s. 577.

${ }^{6}$ Idem, Drogi do porozumienia..., s. 315.

${ }^{7}$ G. Motyka, Ukrainska partyzantka..., s. 401.

${ }^{8}$ Idem, Cień Kłyma Sawura. Polsko-ukraiński konflikt pamięci, Gdańsk 2013, s. 6.

${ }^{9}$ Idem, Ukraińska partyzantka..., s. 430.

${ }^{10}$ Płk Jurij Łopatyńskyj „Szejk”, „Kałyna” (1906-1982) 27 IX 1944 r. został zwolniony przez Niemców z obozu koncentracyjnego i w grudniu tego roku przerzucono go do Galicji. Później wyemigrował do Stanów Zjednoczonych. G. Motyka, Ukraińska partyzantka..., s. 234-235, 430; http://oun-upa.org.ua/encyclopedia/sh.html.

11 AIPN BU 0259/64/1, Protokół przesłuchania Piotra Fedoriwa, Warszawa, 13 II 1948 r., k. 142. Oczywiście nie istniała wówczas jeszcze organizacja WiN. Nieco wcześniej 
Inicjatywa zaprzestania wzajemnej walki ze strony podziemia poakowskiego na Lubelszczyźnie wyszła od ówczesnego komendanta Obwodu Hrubieszów AK por./kpt. Mariana Gołębiewskiego „Stera”, dla którego pojawienie się owego wspólnego wroga w postaci Związku Sowieckiego i polskich komunistów było jednym z czynników determinujących zmianę myślenia ${ }^{12}$. Po wkroczeniu Sowietów oddziały AK nie były w stanie prowadzić, jak za okupacji, walki na dwóch frontach - zabezpieczać ludność przed atakami UPA i skutecznie wymykać się obławom sowieckiego, a potem rodzimego aparatu represji ${ }^{13}$. W opinii kpt. Stanisława Książka, późniejszego komendanta Obwodu Tomaszów Lubelski DSZ, kolejnym czynnikiem wymuszającym zmianę taktyki była oddolna presja społeczna ${ }^{14}$. Jego zdaniem ci, którzy stali na czele konspiracji, musieli liczyć się z opinią lokalnej społeczności, aby nie stracić jej poparcia.

Marian Gołębiewski jako komendant Obwodu Hrubieszów AK, a od wiosny 1945 r. inspektor Inspektoratu Zamość DSZ, następnie od końca czerwca 1945 r. szef sztabu i zastępca Komendanta Okręgu Lublin DSZ i WiN, był głównym zwolennikiem i propagatorem zmiany taktyki. Około 22 września $1944 \mathrm{r}$. w Nowokajetanówce pod Dubienką miała miejsce odprawa Komendy Obwodu Hrubieszów. Obecni byli na niej również oficerowie z innych obwodów, w tym ówczesny komendant NSZ na powiat Chełm Tadeusz Zieliński „Dyzma”. Gołębiewski podjął wówczas temat dalszych relacji polsko-ukraińskich. Powiedziałem im - wspominał po latach - że od tej chwili rozkazuje zamiast toczenia walk przeciw Ukraińcom, szukać z nimi kontaktu i porozumienia ${ }^{15}$. Wśród zebranych oficerów wypowiedź musiała wywołać konsternację. Mówił te słowa w końcu do ludzi, którzy w walkach z Ukraińcami stracili najbliższych. Mówił to również jako osoba, która kilka miesięcy wcześniej opowiedziała się za brutalną akcją

z podobną misją do Polski wyruszył Eugeniusz Sztendera „Zorianyj” „Prirwa”. Przekazał rozkazy, w których była mowa o szukaniu kontaktów z Polakami. Za jego pośrednictwem takie instrukcje dotarły do Jana Szpontaka "Zalizniaka" i jego ludzi. Jednak "Zalizniak" i wielu jego podkomendnych niechętnie patrzyło na nawiązanie współpracy z Polakami Po przejściu na tereny Polski Sztendera w marcu 1945 r. objął stanowisko referenta SB przy prowidzie nadrejonu jarosławskiego. Spotkał się z dowódcą kurenia Janem Szpontakiem „Zalizniakiem”, któremu przekazał rozkazy o zmianie stanowiska wobec Polaków. Kureń „Zalizniaka” należał w tym okresie do najsilniejszych jednostek UPA w Polsce. J. Sztendera, W poszukiwaniu porozumienia (Podziemie ukrainskie i polskie w latach 1945-1947. Wspótpraca pomiędzy UPA i WiN), "Zeszyty Historyczne” 1985, nr 71; G. Motyka, Ukraińska partyzantka..., s. 579 .

12 „Bo mnie tylko wolność interesuje...". Wywiad rzeka z Marianem Gołębiewskim (Nowy Jork, listopad 1988 - czerwiec 1989), oprac. J. Dudek, Lublin 2011, s. 245.

${ }^{13}$ G. Motyka, Tak było w Bieszczadach..., s. 226.

${ }^{14}$ G. Motyka, R. Wnuk, Pany i rezuny..., s. 86; R. Wnuk, Lubelski Okręg AK..., s. 130.

15 „Bo mnie tylko wolność interesuje...", s. 246. 
przeciwukraińską ${ }^{16}$. Z polecenia Gołębiewskiego ówczesny szef hrubieszowskiego BIP-u Bolesław Kłembukowski „Berent” przygotował ulotkę, którą wydrukowano w kilkutysięcznym nakładzie i rozkolportowano na obszarze pomiędzy Włodawą a Jarosławiem. Gołębiewski twierdził, że akcja ulotkowa stosunkowo szybko znalazła pozytywny odzew po stronie ukraińskiej, a walki polsko-ukraińskie wkrótce ustały. Z kolei znawca tego tematu Mariusz Zajączkowski podkreślał, że komendant obwodu Hrubieszów nieco przeceniał ówczesne efekty. Ciągle jeszcze nie tylko na terenie powiatu Hrubieszów, ale i w całej Lubelszczyźnie dochodziło do mordów zarówno na Polakach, jak i Ukraińcach ${ }^{17}$. Na rzeczywiste zaniechanie walk na pograniczu polsko-ukraińskim trzeba było jednak poczekać do wiosny $1945 \mathrm{r} .^{18}$ Choć nawet w przededniu zawarcia zawieszenia broni w Żarach miały miejsce ataki na polskich mieszkańców tych terenów ${ }^{19}$.

Pierwsze kontakty członków UPA z przedstawicielami konspiracji poakowskiej nawiązano na terenie Obwodu Lubaczów DSZ, który sąsiadował z Obwodem Tomaszów Lubelski, ale podlegał strukturom Okręgu Rzeszowskiego DSZ. Właśnie tam w kwietniu 1945 r. doszło do sondażowych spotkań ${ }^{20}$. Niemniej decyzje podejmowane $\mathrm{w}$ tej sprawie $\mathrm{w}$ kwietniu i maju 1945 r. znalazły się w kompetencji Inspektoratu Zamojskiego DSZ $^{21}$. Główne spotkanie 21 maja 1945 r. poprzedziły rozmowy wstępne 2 maja 1945 r. w Dolinach, na których był obecny por. Marian Warda „Polakowski", komendant V rejonu Obwodu Tomaszów Lubelski DSZ, i Mikołaj Wynnyczuk „Wyr", referent organizacyjno-mobilizacyjny i zastępca prowidnyka nadrejonu jarosławskiego OUN. Ukraińcy chcieli nawiązać współpracę i uzyskać kontakty z przedstawicielami polskiego podziemia, gdyż jak podkreślali: Chcemy, aby Polska odegrała swoja dominujaca role

${ }^{16} \mathrm{Na}$ ten temat zob. M. Zajączkowski, Ukraińskie podziemie na Lubelszczyźnie w okresie okupacji niemieckiej 1939-1944, Lublin-Warszawa 2015, s. 282-308.

${ }_{17}$ M. Zajączkowski, Działalność Organizacji Ukraińskich..., s. 459, 425, 462; R. Ziętek, Konflikt polsko-ukraiński na Chetmszczyźnie i potudniowym Podlasiu w okresie okupacji niemieckiej, „Rocznik Chełmski” 2001, s. 244-246.

${ }^{18}$ M. Zajączkowski, Działalność Organizacji Ukraińskich..., s. 468.

${ }^{19}$ G. Motyka, Cień Kłyma Sawura...., s. 6. Za koniec „antypolskiej akcji” uznaje się rajd sotni „Wilki”, która w maju 1945 r. w kilku miejscowościach Lubelszczyzny zamordowała kilkadziesiąt osób.

${ }^{20}$ M. Zajączkowski, Drogi do porozumienia..., s. 288.

${ }^{21}$ Według Grzegorza Ostasza wiosną 1945 r. inspektor rzeszowski mjr Adam Lazarowicz zakazał kontaktów z UPA. I spotkanie na terenie pow. Lubaczów potraktował jako niepodporządkowanie się jego rozkazom. Jednak jaki pisze dalej ten sam autor, później dostrzegł korzyści wypływające z zaprzestania wzajemnych walk. G. Ostasz, Okręg Rzeszowski Zrzeszenia "Wolność i Niezawistość". Model konspiracji, struktura, dzieje, Rzeszów 2006, s. 489. 
wśród narodów słowiańskich. „Polakowskiemu” przedłożono następujące kwestie podlegające uzgodnieniu: 1. Przejście oddziałów naszych do nich i odwrotnie w razie akcji bolszewickiej. 2. Wspólna akcja przeciw bandytyzmowi. Pomoc aprowizacyjna przy przenoszeniu na obcy teren. 3. Ochrona ludności cywilnej pod każdym względem. 4. Anulowanie wszystkich dotychczasowych pretensji ludności do strat materialnych. 5. Walka ze szpiegostwem. Wymiana protokołów po egzekucjach. 6. Udzielanie wzajemne wywiadu wojennego. 7 Wymiana prasy 22 .

Do głównego spotkania, w trakcie którego omawiano powyższe postulaty, doszło 21 maja 1945 r. w Żarze, przysiółku Lublińca Nowego ${ }^{23}$. W rozmowach udział wzięli: kpt. Marian Gołębiewski jako inspektor Inspektoratu Zamość DSZ (uczestniczył tylko raz w spotkaniu z delegacją ukraińską); kpt. Stanisław Książek „Rota”, komendant Obwodu Tomaszów Lubelski DSZ i jednocześnie zastępca Gołębiewskiego; por. Jan Turowski „Norbert”, adiutant inspektora Inspektoratu Zamość DSZ; kpr. Józef Borecki „Wdowa”, „Komar”, adiutant komendanta Obwodu Tomaszów Lubelski DSZ; por. Marian Warda „Polakowski”, „Mały”, ko-

${ }^{22}$ Ł. Kamiński, op. cit., s. 160-161.

${ }^{23} \mathrm{~W}$ literaturze przedmiotu przez wiele lat pisano, że główne spotkanie miało miejsce w Rudzie Różanieckiej. Jako pierwsi pisali o tym autorzy książki Droga donikąd Antoni B. Szcześniak i Wiesław Z. Szota, którzy wskazywali na tę miejscowość, kierując się zeznaniami Piotra Fedoriwa „Dalnycza”, krajowego referenta Służby Bezpieczeństwa OUN-B. Kolejni autorzy podejmujący ten temat Rafał Wnuk i Grzegorz Motyka („Pany i rezuny...", s. 88) również wskazywali na Rudę Różaniecką jako miejsce spotkania w dniu 21 V 1945 r. W wątpliwość ustalenia te podał Mariusz Zajączkowski, który jako najbardziej prawdopodobne miejsce spotkania wskazywał dwa z przysiółków Lublińca Nowego: Ostrówki bądź Żary. Jeszcze inni historycy wskazywali na Doliny - przysiółek Żukowa, m. in. Franciszek Gajerski, Tomasz Bereza i Tomasz Róg. Wątpliwości te rozwiał Mariusz Moszkowicz, który analizując literaturę, dokumenty archiwalne, a także zbierając relacje pośród lokalnej społeczności ustalił, że tym miejsce były właśnie Żary - przysiółek Lublińca Nowego. Obecnie miejscowość ta nie istnieje. $W$ miejscu, gdzie kiedyś rozpościerała się wieś, rośnie las, a jedynym widocznym znakiem jej istnienia są murowane przydrożne kapliczki. Przed wojną miejscowość zamieszkana była w całości przez ludność ukraińską. Żary jako miejsce spotkania podał też Marian Warda „Polakowski” w czasie jednego z przesłuchań w PUBP $\mathrm{w}$ Tomaszowie Lubelskim i również obecny tam ppor. Edmund Krzyżanowski „Dębno". Miejscowość ta także pojawiła się we wspomnieniach Mychajły Szymańskiego (1947. Propamjatna Knyha), który dowodził ukraińską ochroną zabezpieczającą spotkanie. Wątpliwości i spory występowały także w literaturze odnośnie do daty głównego spotkania. Jednak zachowane dokumenty archiwalne wskazują bez wątpienia, że odbyło się 21 V 1945 r. Co prawda sam Gołębiewski jak i Stanisław Książek po kilkudziesięciu latach nie byli pewni, kiedy doszło do głównego spotkania 5 czy 21 maja, ale poza własną pamięcią nie mogli odwołać się do innych źródeł informacji. M. Zajączkowski, Drogi do porozumienia..., s. 289; M. Moszkowicz, op. cit., s. 71-86; AIPN Lu, 17/978, Protokół przesłuchania Mariana Wardy, Tomaszów Lubelski, 8 VIII 1946 r., k. 7; „Bo mnie tylko wolność interesuje...", s. 259-262. 
mendant V rejonu Obwodu Tomaszów Lubelski DSZ; ppor. Stefan Pluta „Stal” dowódca 5. kompanii (placówki) Dzików Stary V rejonu Obwodu Tomaszów Lubelski DSZ oraz ppor. Edmund Krzyżanowski „Dębno”, dowódca 2. Kompanii (placówki) Ruda Różaniecka V rejonu Obwodu Tomaszów Lubelski DSZ ${ }^{24}$. W wątpliwość historycy obecnie podają udział w spotkaniu kpt. Franciszka Przysiężniaka „Ojca Jana” z Okręgu Rzeszów $\mathrm{NZW}^{25}$. Po stronie ukraińskiej obecni byli: ppłk Jurij Łopatynśkyj „Szejk”, przedstawiciel UHWR i głównego dowództwa UPA; Mykoła Wynnyczuk „Kornijczuk”, „Wyr” oraz Sergiusz Martyniuk „Hrab”, wówczas referent propagandy przy Kierownictwie Okręgu III OUN obejmującego Lubelszczyznę.

Kpt. Gołębiewski był zaskoczony pojawieniem się na spotkaniu ukraińskich delegatów tak wysokiego szczebla: [...] ja nie spodziewatem się tego rodzaju wysokiego stopnia przedstawicieli ukrainskich - mówił w latach dziewięćdziesiątych - dlatego, że mnie chodziło głównie o uspokojenie, raz terenu, dwa ubezpieczenie się przed prowokacjami rosyjskimi, NKWD itd. i dalsza rzecz dopiero nawiazanie wspótpracy ${ }^{26}$.

Rozmowy trwały wiele godzin. Prowadzono je głównie w języku polskim. Towarzyszyło im niemałe napięcie i obopólna nieufność. Kiedy spojrzymy na zdjęcia ze spotkania, zobaczymy ludzi ze skrzyżowanymi dłońmi, trzymających ręce $\mathrm{w}$ kieszeniach czy nerwowo bębniących palcami o stół. Podczas rozmowy ogladaliśmy się wzajemnie - relacjonował wiele lat później Stanisław Książek ${ }^{27}$. Strona ukraińska zgodnie z przedstawionymi na wcześniejszych spotkaniach punktami porozumienia proponowała zaprzestanie walk oraz wzajemną współpracę w walce przeciwko Sowietom. Konkretnie ze strony ukraińskiej zostały wysunięte następujace propozycje - pisał „Ster" po spotkaniu w raporcie do przełożonych: 1. zawarcie pewnego rodzaju paktu nieagresji na podstawie obecnego stanu posiadania (status quo); 2. rozpoczęcie ścisłej wspótpracy w sensie urabiania opinii obu

${ }^{24}$ M. Moszkowicz, op. cit., s. 82-83.

${ }^{25} \mathrm{O}$ jego obecności w Żarach mówił kpt. Stanisław Książek (obaj panowie znali się jeszcze sprzed wojny, gdyż służyli w latach 1931-1932 w szkole Podchorążych Rezerwy Artylerii we Włodzimierzu Wołyńskim). Jednak obecności Przysiężniaka nie potwierdza zachowana dokumentacja fotograficzna. Zdaniem Mariusza Zajączkowskiego Przysiężniak był obecny na jednym ze spotkań sondażowych w Dolinach, lecz w Żarach raczej nie. Na wątpliwy udział „Ojca Jana” wskazuje również Dariusz Iwaneczko w opublikowanej niedawno biografii Karola Kosteckiego. M. Zajączkowski, Działalność Organizacji Ukraińskich..., s. 477-478; M. Moszkowicz, op. cit., s. 83; D. Iwaneczko, „Przypadek czy przeznaczenie?". Karol Kazimierz Kostecki „Kostek” (1917-1998), Rzeszów 2013, s. 121.

${ }^{26}$ Zapis spotkania między Marianem Gołębiewskim a Jewhenem Sztenderą w IJP w Nowym Yorku około 1991 r. Zbiory Tomasza Gołębiewskiego.

${ }^{27}$ G. Motyka, R. Wnuk, Pany i rezuny ..., s. 89-90. 
narodów za obopólnym wspótżyciem (wymiana, prasy, artykułów i informacji); 3. trwała umowa winna być podpisana przez czynniki Polskiego Ruchu Podziemnego i przez nie opublikowana. 4. układ powinien być gwarantowany przez rzad polski w Londynie ${ }^{28}$. "Szejk" przedstawił ponadto idee utworzenia bloku narodów ujarzmionych przez ZSRR, który miał być wzmocniony przez udział w niej Polski ${ }^{29}$. Chodziło tu o powołanie związku/federacji narodów, który miałby na celu rozsadzenie Zwiazku Sowieckiego i przyspieszenie wojny $z$ Rosją. Ponieważ Polska posiada $w$ danym momencie oficjalne przedstawicielstwo polityczne w postaci rzadu polskiego w Londynie, Ukraińcy proponuja, by inicjatywa stworzenia tego bloku wyszła ze strony Polskikontynuował „Ster" ${ }^{\prime 30}$.

Propozycje ukraińskie zrobiły duże wrażenie na polskiej delegacji ${ }^{31}$. Adiutant Gołębiewskiego, Jan Turowski „Norbert”, po aresztowaniu w 1946 r. przesłuchującemu go funkcjonariuszowi WUBP w Lublinie mówił o reakcji przełożonego: [...] "Ster" [Marian Gołębiewski - J.D.] podkreślat, że nie jest on uprawniony do zawarcia ze strona Ukrainska wiążacego układu, gdyż o tym zadecydować moga tylko czynniki wyższe i że jemu w pierwszym rzędzie chodzi o "zagojenie ran w pasie walk" i o zapobieżenie wzajemnemu [słowo nieczytelne] rozlewowi krwi. Zaznaczył też "Ster", że wyniki rozmów przedstawi władzy przełożonej i jej reakcje $[\ldots]^{32}$. Dla strony ukraińskiej najważniejszą sprawą był wizja nawiązania kontaktu z kierownictwem DSZ w Warszawie, a za jej pośrednictwem z polskim Londynem ${ }^{33}$.

Delegacja ukraińska poruszyła także wrażliwy temat przyszłej granicy. Zdecydowano się na utrzymanie linii Curzona, ale sprawa ta miała

${ }^{28}$ „Bo mnie tylko wolność interesuje...”, s. 372. Zob. również J. Sztendera, op. cit., s. 165.

${ }^{29}$ Protokół ze spotkania władz AK z przedstawicielami ukraińskimi w dniu 21 maja 1945 r. zob. Ł. Kamiński, op. cit., s. 162. Koncepcja budowania związku narodów znajdujących się pod supremacją ZSRR była najwyraźniej zmienioną i dopasowaną do ówczesnych warunków kontynuacją planu, który w kierownictwie OUN pojawił się jesienią $1943 \mathrm{r}$. G. Motyka, Ukraińska partyzantka..., s. 126.

30 „Bo mnie tylko wolność interesuje...", s. 372. G. Motyka, R. Wnuk, Pany i rezuny na emigracji. Próby porozumienia polsko-ukraińskiego na Zachodzie 1945-1950, „Więź" 2000, nr 9, s. 202; G. Motyka, Ukraińska partyzantka..., s. 126. W listopadzie 1943 r. na Ukrainie odbyło się spotkanie zorganizowane przez OUN-B, w którym udział wzięli przedstawiciele różnych nacji z terenu ZSRR. I Konferencja Zniewolonych Narodów Europy Wschodniej i Azji odbyła się 21-22 XI 1944 r. Nie miała ona większego znaczenia, aczkolwiek w banderowskiej historiografii uznawano ją za ważne wydarzenie. Pomysł ten w 1948 r. przerodził się w stworzony przez UHWR i członków OUN-B Antybolszewicki Blok Narodów zorganizowany na emigracji.

${ }^{31}$ G. Motyka, R. Wnuk, Pany i rezuny..., s. 91.

${ }^{32}$ AIPN Lu, 17/978, Protokół przesłuchania Jana Turowskiego, 23V 1947 r., k. 115.

${ }^{33}$ M. Zajączkowski, Działalność Organizacji Ukraińskich.., s. 479. 
być omówiona później przez bardziej uprawnionych do tego przedstawicieli polskiego podziemia. Zdaniem Mariusza Zajączkowskiego ukraińskie podziemie raczej nigdy nie przestało myśleć o włączeniu ziem położonych na zachód od linii Curzona do przyszłego państwa ukraińskiego $^{34}$. Podobnie jak Polacy, którzy mieli nadzieję na powrót Lwowa do Polski. Inspektor "Ster” obiecał ukraińskim delegatom, że dołoży wszelkich starań, aby umożliwić im kontakt z polskimi władzami na wyższym szczeblu ${ }^{35}$.

W konsekwencji spotkania doszło do porozumienia/rozejmu, co oznaczało lokalne zawieszenie broni obejmujące Zamojszczyznę, powiat Lubaczów i Chełm ${ }^{36}$. Postanowiono o zaprzestaniu działań zbrojnych wobec ludności cywilnej obu stron; wyznaczono strefy wpływów w terenie, reguły poruszania się na obszarze kontrolowanym przez jednych i drugich, a także uzgodniono zasady działalności propagandowej, wywiadowczej i wojskowej. Zobowiązano się do zwalczania bandytyzmu, który był plagą pierwszych lat po zakończeniu okupacji niemieckiej. Natomiast, aby uniknąć podejrzeń o mordowanie niewinnych ludzi, sądzenie osób narodowości polskiej na terenie kontrolowanym przez UPA wymagało konsultacji z AK i odwrotnie ${ }^{37}$.

Zawieszenie broni zawarte z Żarze zostało w październiku $1945 \mathrm{r}$. rozszerzone na teren południowego Podlasia. Objęło powiaty: chełmski, włodawski, bialski, łukowski i radzyński. Tam do głównego spotkania doszło nocą z 27 na 28 października w Tucznej. Ze stroną ukraińską reprezentowaną przez Sergiusza Martyniuka "Hraba” spotkali się mjr Jan Szatkowski-Szatyński „Zagończyk” (wobec UPA występujący jako „Dziryt"), inspektor Inspektoratu Biała Podlaska WiN, a w 1944 r. dow. 27 Wołyńskiej DP; kpt. Władysław Nikszto „Żuk” (występujący jako „Pająk”), szef wywiadu Okręgu Lublin, oraz Cyprian Wierzchowski, komendant

\footnotetext{
${ }^{34}$ Idem, Działalność Organizacji Ukraińskich..., s. 464-465.

${ }^{35}$ Idem, Drogi do porozumienia..., s. 294.

${ }^{36}$ Ibidem.
}

37 Zdarzały się odstępstwa od zawartego rozejmu i próby jego storpedowania. M. Zajączkowski, Drogi do porozumienia..., s. 300-305. Ze względu na specyfikę południowego Podlasia (duża liczba przesiedleńców zza Bugu, spory odsetek ludności ukraińskiej o lewicowych sympatiach) dochodziło tu częściej do jego łamania niż na Zamojszczyźnie. Pomimo tego zawarte w 1945 r. zawieszenie broni/rozejm/porozumienie przetrwało w zasadzie do akcji „Wisła” w 1947 r. Najbardziej widocznym efektem były wspólne polsko-ukraińskie akcje zbrojne, z których najgłośniejszą był napad z 27 na 28 maja $1946 \mathrm{r}$. na Hrubieszów. Liczące siły WiN, UPA i bojówek SB OUN zaatakowały budynek PUBP, KP MO, KP PPR i koszary, gdzie stacjonował III batalion 98 pułku 64 dywizji Wojsk Wewnętrznych NKWD 
rejonu V Obwodu Biała Podlaska. Warunki były tego samego rodzaju, co podczas spotkania w maju $1945 \mathrm{r}^{38}$

22 maja 1945 r., czyli dzień po spotkaniu z delegacją ukraińską kpt. Marian Gołębiewski „Ster" przygotował meldunek, który dotarł do Warszawy w pierwszych dniach czerwca 1945 r., czyli w momencie gdy Okręgowi Lublin DSZ udało się ponownie nawiązać łączność zerwaną z Obszarem Centralnym DSZ ${ }^{39}$. Informował w nim o odbytym spotkaniu, prowadzonych rozmowach, a także ukraińskich propozycjach i oczekiwaniach. Podkreślał, że miały one charakter wstępny i informacyjny. Ze swej strony [...] - pisał do przełożonych - zdecydowałem się na zawieszenie walk $i$ przyrzekłem ułatwienie kontaktu delegatów ukraińskich z czynnikami polskimi ${ }^{40}$. Meldował jednocześnie o kolejnym spotkaniu, które zaplanowano na 16 czerwca $1945 \mathrm{r}$.

W tym momencie dochodzimy do kluczowego wątku - czyli jak zareagował delegat Delegatury Sił Zbrojnych płk Jan Rzepecki na informacje o rozmowach z przedstawicielami ukraińskiego podziemia. Dotychczas $\mathrm{w}$ literaturze przedmiotu pisano jedynie o zdystansowanej reakcji płk. Jana Mazurkiewicza „Radosława”, ówczesnego delegata Obszaru Centralnego DSZ. Właśnie kpt. Marian Gołębiewski w relacjach, jakie składał w latach 80. i 90., często podkreślał lekceważący stosunek do współpracy z UPA płk. „Radosława”, który jego zdaniem nie polecił ani z nimi walczyć, ani współpracować ${ }^{41}$.

Meldunek kpt. „Stera”, za pośrednictwem płk. „Radosława”, został przekazany delegatowi Delegatury Sił Zbrojnych na Kraj płk. Janowi Rzepeckiemu. Trafił w jego ręce na początku czerwca 1945 r. Rzepecki wspominał: [...] 15 lub 16 czerwca otrzymałem meldunek "Radosława", że udało mu się odbudować łączność z Lublinem, co prócz wiadomości o położeniu przyniosto także ciekawy raport akowskiego inspektora "Stera" [...] o nawiazaniu z nim kontaktów przez „Ukraińska Powstańczą Armię". [...] [Marian Gołębiewski J. D.] umówił następne spotkanie na 16 czerwca /tj. na dzień, w którym dopiero czytałem jego raport/42. Tymczasem zachowana w Bibliotece UW kopia meldunku przeznaczona do „Centrali” w Londynie nosi datę 7 VI 1945 r. Zapewne Rzepecki wspominając po latach po prostu nie pamiętał dokładnej

\footnotetext{
${ }^{38}$ G. Motyka, R. Wnuk, Pany i rezuny..., s. 105-121; J. Kopiński, op. cit., s. 58-62; M. Zajączkowski, Drogi do porozumienia..., s. 296.

${ }^{39}$ Łączność między Okręgiem Lublin AK a KG AK została zerwana w lecie 1944 r. po wkroczeniu na Lubelszczyznę Armii Czerwonej.

${ }^{40}$ "Bo mnie tylko wolność interesuje...", s. 371-373.

${ }^{41}$ G. Motyka, R. Wnuk, Pany i rezuny..., s. 181; „Bo mnie tylko wolność interesuje...”, s. 255-256.

${ }^{42}$ SPP, B. I.35, Relacja Jana Rzepeckiego, k. 125. BUW, BIP KG AK, syg. 2136.
} 
daty. Sprawa ukraińskich propozycji była wówczas omawiana w wąskim gronie. Rzepecki zanim podjął jakiekolwiek decyzje, skonsultował się z p. o. delegata Rządu na Kraj Stefanem Korbońskim, a także przedwojennym wojewodą wołyńskim Henrykiem Józewskim, który był w tym czasie jego doradcą ${ }^{43}$. Ponad to o całej sprawie wiedział ówczesny szef BIP Kazimierz Moczarski. Józewski zwracał uwagę na potrzebę prowadzenia propolskiej propagandy w szeregach UPA i emigracji na Zachodzie. W kwestii granicy stwierdził: Myślac o możliwościach powrotu do Lwowa starajmy się zapewnić tę granice, która mamy ${ }^{44}$.

Płk Jan Rzepecki „Ożóg” przygotował w sprawie ukraińskich propozycji meldunek dla Londynu, który prezentował oficjalne stanowisko DSZ wobec faktu nawiązania kontaktów z ukraińskim podziemiem przez podziemie poakowskie na Lubelszczyźnie. Pisał w nim: 21 maja przedstawiciele UPA i Ukr[aińskiej] Hławnej Wyzw. Rady - tymcz[asowego] rzad - proponowali insp[ektorowi] Zamość: zaprzestanie walk z pol., wspótprace propag[andową] za zgodnym wspótżyciem, trwata umowę z Pol[skim] Podziem[iem]i zagwarant[owanie] jej przez rzad RP. Oświadczyli, że dą̇a do feder[acji] narodów ujarzm[ionych] przez ZSRR w celu przyspiesz[enia] wojny $z$ Ros[ją] i rozsadzenia ZSow. W poroz[umieniu] z DR zarzadziłem utrzymanie stosunków z UPA przy całkow[itym] zawieszeniu walk, wzaj[emną] pomoc $w$ samoobr[onie], niewspótdziałanie gdy UPA atakuje, wzajemne oszczędzanie ludności, propagande współżycia, podkreślenie niemożliwości wprowadzenia przez rzad RP sprawy ukr [aińskiej] na rynek dyplomat [yczny], niesporzadzanie żadnej umowy pisem[nej]. Poleciłem doradzić działanie przez emigr[ację. Nastęny kontakt z Ukr. 15 czerwca ${ }^{45}$. Wynika z niego jasno, że porozumienie między OUN-B i UPA a podziemiem poakowskim zostało zaakceptowane $\mathrm{w}$ formie lokalnego zawieszenia broni przez Delegaturę Sił Zbrojnych.

Jeszcze w czerwcu 1945 r. Rzepecki przekazał delegatowi Obszaru Centralnego płk. „Radosławowi” stanowisko DSZ w kwestii ukraińskich propozycji. Pisał, aby: Pochwalić insp[ektora] "Stera" za rozsadne postawienie sprawy $^{46}$. Jednocześnie, o czym wspominał po latach, nie był zadowolony z takiego obrotu sprawy, ponieważ ten, jak sam pisał o Gołębiewskim

${ }^{43}$ SPP, B. I. 35, Relacja Jana Rzepeckiego, k. 125-126; M. Gałęzowski, Henryk Józewski „Olgierd", "Zeszyty Historyczne” 2004, z. 150, s. 115. Józewski przygotowywał również odezwy, które były drukowane przez DSZ.

${ }_{44}^{4}$ SPP, B. I. 35, Relacja Jana Rzepeckiego, b. p.

${ }^{45}$ BUW, BIP KG AK, syg. 2136, Meldunek dotyczący rozmów ze stroną Ukraińska, przeznaczony dla „Centrali”, 7 VI 1945 r., k. 18.

46 SPP, B.I.35, Pismo Komendanta DSZ płk Jana Rzepeckiego do Komendanta Obszaru Centralnego DSZ płk. Jana Mazurkiewicza „Radosław” w sprawie spotkania UPA i UHWR 21 V 1945 r.; „Bo mnie tylko wolność interesuje...”, s. 374. 
nieznany mu podwładny, postawił go przed faktem dokonanym ${ }^{47}$. [...] "Ster" okazat dobre zorientowanie polityczne i sprawe postawit nieźle - pisał we wspomnieniach płk Jan Rzepecki - ale wytworzył położenie, w którym nie miałem ochoty znajdować się. W dodatku, gdy dopiero zastanawiatem się co $z$ tym zrobić, on tam już odbyt nowa rozmowe $i$ stwarzat nowe fakty dokonane, za które odpowiedzialność ponosit Korboński i ja. ${ }^{48} \mathrm{Z}$ pewnością nie bez racji pisali Grzegorz Motyka i Rafał Wnuk, że korzyści z zawieszenia broni dostrzegane w terenie z perspektywy „,wielkiej polityki” były mało istotne ${ }^{49}$. Ale w świetle przedstawionego meldunku płk. Rzepeckiego do „Centrali” wydaje się, że wykazywał on zrozumienie wobec konieczności ułożenia relacji polsko-ukraińskich na poziomie lokalnym. Nie widział co prawda możliwości, aby Rząd Polski w Londynie stał się rzecznikiem sprawy ukraińskiej na arenie dyplomatycznej, na czym tak bardzo zależało stronie przeciwnej ${ }^{50}$. Choć całkowicie tego nie wykluczał w przypadku zmiany sytuacji międzynarodowej, na przykład wybuchu wojny sowiecko-angielskiej ${ }^{51}$. Doradzał Ukraińcom szukanie kontaktów z Zachodem raczej przez swoją emigrację w Ameryce aniżeli przez przedstawicieli polskiego rządu. Proponował jedynie: możemy przekazać ich [Ukraińców - J. D.] krótkie telegramy ${ }^{52}$.

Można się zastanawiać, czy płk Jan Rzepecki otrzymał z Londynu jakieś wytyczne w sprawie polsko-ukraińskiego spotkania? W zbiorach Biblioteki Uniwersytetu Warszawskiego zachował się dokument, który ze względu na treść można by uważać za taką odpowiedź, ale równie dobrze i chyba bardziej prawdopodobne wydaje się, że jest to opinia przygotowana w Delegaturze Rządu. Mowa tu o dokumencie zatytułowanym Notatka w sprawie rozmów polsko-ukraińskich, sporządzonym przez nieznaną osobę, bez daty i miejsca ${ }^{53}$. Mariusz Zajączkowski charakteryzując działania strony polskiej pisał, że w jej zachowaniu z biegiem czasu: [...] zaczęła odgrywać [rolę - J. D.] chłodna kalkulacja polityczna ${ }^{54}$. Słowa te dobrze

\footnotetext{
${ }^{47}$ Rzepecki poznał Mariana Gołębiewskiego dopiero w więzieniu na Mokotowie w styczniu $1946 \mathrm{r}$.

${ }^{48}$ SPP, B. I.35, Relacja Jana Rzepeckiego, k. 126.

${ }^{49}$ G. Motyka, R. Wnuk, Pany i rezuny..., s. 184.

${ }^{50}$ „Bo mnie tylko wolność interesuje...", s. 374.

${ }^{51}$ Ibidem, s. 374. Historycy, pisząc o decyzji płk. Jana Rzepeckiego powołania nowej cywilnej organizacji, podkreślaja, że był ona realistą i nie wierzył w szansę wybuchu nowego konfliktu zbrojnego. T. Honisz, Zrzeszenie "Wolność i Niezawisłość” [w:] Armia Krajowa. Dramatyczny epilog, red. K. Komorowski, Warszawa 1994, s. 91.

${ }^{52}$ Ibidem.

${ }^{53}$ BUW, BIP KG AK, syg. 2136, Notatka w sprawie rozmów polsko-ukraińskich, bez daty, k. 19-20.

${ }^{54}$ M. Zajączkowski, Działalność Organizacji.., s. 481.
} 
oddają podejście wyrażone we wspomnianym dokumencie. Strona polska przyjmuje z zadowoleniem do wiadomości - pisano w notatce - oświadczenie strony ukraińskiej o zaprzestaniu walk, propozycje paktu nieagresji, propozycje wspótdziałania w samoobronie przed terrorem sowieckim i zapowiedzi propagan$d y$ "współżycia”. Pozwala to mieć nadzieje, że rozmowy polsko-ukraińskie doprowadza do pomyślnego dla obu stron wyniku. Strona polska deklarowała gotowość podjęcia rozmów z przedstawicielami ukraińskim, ale pod kilkoma warunkami, mianowicie: 3. Ukraincy musza wykazać dobra wole nie tylko w słowach, lecz w czynach. Wykazanie tego wymaga czasu, to znaczy musi przejść pewien okres, który dostarczy faktów potwierdzajacych realność intencji strony ukraińskiej - okres przygotowawczy. W czasie jego trwania gromadzić się będzie materiat, na podstawie którego można będzie przystapić do sformułowania politycznego stanowiska, uznanego przez czynniki miarodajne obu narodów $w^{55}$. Ponadto domagano się kategorycznego potępienia zbrodni dokonanych przez UPA na Polakach, wezwania społeczności ukraińskiej do współpracy z Polakami, szerzenia propolskiej propagandy oraz potwierdzenia tego czynami poprzez współdziałanie z Polakami w samoobronie i walce $z$ Sowietami ${ }^{56}$. Podejście strony polskiej było podyktowane nieufnością, ale i obawą prowokacji, dlatego zalecano w dalszych kontaktach zachować daleko idącą ostrożność. Wyjaśnienia wymagało szereg problemów szczegółowych. Chciano poznać stanowisko strony ukraińskiej co do następujących zagadnień: 1 - jak rozumieja federacje, 2 - jak zapatruja się na zagadnienie terenów mieszanych, 3 - jaka jest w ich mniemaniu rola Polski w ksztattowaniu życia ukraińskiego, społecznego, państwowego i kulturalnego, 4 - jak wyobrażaja sobie stosunek do państwa polskiego i jak wyobrażaja sobie rozwiazanie ukrainskie w chwili obecnej na forum międzynarodowym [...]. Musimy twardo stać na stanowisku "okresu przygotowawczego" - pisano w podsumowaniu - do chwili wyjaśnienia sytuacji. Nie możemy obecnie angażować prestiżu rządu polskiego. Ostrożne stanowisko było podyktowane także tym, że nie wiedziano, czy strona ukraińska jest miarodajnym czynnikiem reprezentującym ukraińskie społeczeństwa. Sądzono, że raczej nie.

Podsumowując należy stwierdzić, że inicjatywa podjęta przez kpt. "Stera", wbrew temu co on sam twierdził po latach, została w czerwcu 1945 r. zaakceptowana przez DSZ w wersji lokalnej samoobrony i zawieszenia broni. Natomiast dalszymi kontaktami z Ukraińcami miała zająć się Delegatura Rządu w Lublinie. Rzepecki pisał: [...] postanowiliśmy cata

\footnotetext{
${ }^{55}$ BUW, BIP KG AK, syg. 2136, Notatka w sprawie rozmów polsko-ukraińskich, bez daty, k. 19-20.

${ }^{56}$ Ibidem, k. 19.
} 
polityczna strone tych kontaktów odebrać z rąk "Stera" ${ }^{57}$. Nic jednak takiego nie nastąpiło.

Do 22 czerwca 1945 r. kpt. Gołębiewski, jako inspektor zamojski, nie otrzymał żadnych instrukcji, jakiej odpowiedzi ma udzielić ukraińskim delegatom. W związku z tym sporządził kolejny meldunek adresowany do Okręgu Lublin DSZ i przesłał nowe materiały otrzymane od strony ukraińskiej. W połowie czerwca 1945 r. najprawdopodobniej w Dolinach, zgodnie z majowymi ustaleniami, doszło do kolejnego spotkania, jednak kpt. „Ster” na nim się nie zjawił, a wysłał kogoś o niższej randze i mniejszych kompetencjach ${ }^{58}$. Przedstawiciele ukraińscy, którzy przyjechali na spotkanie, wysunęli kolejne postulaty i prośby, o których Gołębiewski informował Okręg Lublin DSZ: Na ostatniej konferencji przeprowadzonej z przedstawicielami Głównej Wyzwoleńczej Rady Ukraińskiej i UPA z ich strony wysunięte zostały następujace dezyderaty: 1/ Umożliwienie przetransportowania przedstawiciela ich do Anglii celem nawiazania łązności z Rzadem Polskim, 2/Umieszczenie przedstawiciela ich przy Delegaturze Krajowej, 3/ Wspólne oddziaływanie celem wstrzymania wysiedlen, 4/Ujednolicenie akcji na całym odcinku styku polsko-ukraińskiego oraz nawiazanie kontaktów na całej linii, 5/ Wymiane pism centralnych ${ }^{59}$. Przekazał ponadto Myśli w sprawie uregulowania polsko-ukraińskich stosunków w sprawie stworzenia wspólnego frontu wyzwolenia, sporządzone 19 czerwca 1945 r. przez „Szejka”, „Hraba” oraz "Zira”, i ponownie prosił o przystanie przedstawiciela wzgl[ędnie] o wytyczne ${ }^{60}$. Wkrótce potem kpt. Marian Gołębiewski został powołany przez komendanta Okręgu Lublin DSZ płk Wilhelma Szczepankiewicza „Drugaka” na stanowisko jego zastępcy i szefa sztabu. Niewątpliwie ten awans ułatwił mu kontakty na szczeblu centralnym.

Zanim stanowisko DSZ dotarło w teren, minęły co najmniej dwa miesiące. Jak wynika z literatury, kpt. „Ster” stanowisko Rzepeckiego otrzymał pod koniec lipca 1945 r. na odprawie u Jana Mazurkiewicza „Radosława" ${ }^{\prime \prime 1}$. Wkrótce jednak straciło ono na aktualności. Już od przełomu maja i czerwca 1945 r. zastanawiano się w kierownictwie DSZ nad możliwością powołania $\mathrm{w}$ jej miejsce organizacji o charakterze politycznym ${ }^{62}$. Zawirowania polityczne $\mathrm{w}$ szeregach poakowskiej konspiracji, spowodowa-

\footnotetext{
${ }^{57}$ SPP, B. I.35, Relacja Jana Rzepeckiego, k. 127.

${ }^{58}$ A. B. Szcześniak, W. Z. Szota, op. cit. s., 333; M. Zajączkowski, Działalność Organizacji Ukraińskich..., s. 480-481.

${ }^{59}$ BUW, BIP KG AK, syg. 2136, Meldunek „Stera” do „Społem” [Okręgu Lublin], 22 VI 1945 r., k. 22.

${ }^{60}$ BUW, BIP KG AK, syg. 2136, k. 30, 42.

${ }^{61}$ G. Motyka, R. Wnuk, Pany i rezuny..., s. 181.

${ }^{62}$ A. Chmielarz, Powstanie i działalność I Zarzadu Głównego Zrzeszenia WiN, „Zeszyty Historyczne WiN-u" 2006, nr 25, s. 6
} 
ne powrotem do kraju Stanisława Mikołajczyka, który wszedł w skład Tymczasowego Rządu Jedności Narodowej, a następnie rozwiązanie DSZ (6 VIII 1945 r.) zaowocowały powstaniem cywilnej organizacji w postaci Zrzeszenia Wolność i Niezawisłość, którego I Komenda odcięła się od rządu emigracyjnego.

Sprawa stosunku I Zarządu Głównego WiN do kwestii porozumienia z podziemiem ukraińskim może być problematyczna z tego względu, że jedynym źródłem są tu protokoły z przesłuchań oraz procesu, zaś proces I KG WiN ze stycznia 1947 r. miał do spełnienia konkretne zadania propagandowe. Nie tylko zmierzał do złamania woli oporu w społeczeństwie w przededniu wyborów do Sejmu Ustawodawczego, ale miał pokazać, jak mówił prof. Andrzej Friszke, że podziemie prowadzi na manowce, do zguby $i$ jest bez sensu ${ }^{63}$.

Po aresztowaniu przez MBP 1 sierpnia 1945 r. płk. Jana Mazurkiewicza „Radosława” jego miejsce na stanowisku delegata Obszaru Centralnego DSZ, a później WiN sprawował Józef Rybicki „Maciej”. On również został zatrzymany przez MBP kilka miesięcy później, w grudniu 1945 r. Podczas jednego z przesłuchań zeznawał, że gdy spotkał się z „Radosławem” w okresie akcji ujawnieniowej, ten ostrzegał go, że będzie miat kiedyś duże przykrości, gdyż w okręgu lubelskim dzieja się świństwa ${ }^{64}$. Można domniemywać, że płk. Mazurkiewiczowi chodziło właśnie o kontakty z podziemiem ukraińskim. Józef Rybicki utrzymywał, że jako delegat Obszaru Centralnego WiN o całej sprawie dowiedział się dopiero na przełomie sierpnia i września 1945 r., gdy podczas spotkania z komendantem Okręgu Lublin płk. Wilhelmem Szczepankiewiczem „Drugakiem” ten zapytał go o stan kwestii ukraińskiej ${ }^{65}$. Rybicki poprosił wówczas o przesłanie mu wszystkich materiałów, ponieważ w spuściźnie po „Radosławie” nie było żadnych dokumentów na ten temat ${ }^{66}$. Dokumenty te w listopadzie $1945 \mathrm{r}$. zostały mu przekazane ${ }^{67} .4$ listopada $1945 \mathrm{r}$. Rybicki przedstawił tę sprawę na zebraniu Komendy Głównej Zrzeszenia w Łodzi ${ }^{68}$. Specjalnie szkodli-

${ }^{63}$ P. Lipiński, Raport Rzepeckiego. Historia twórcy antykomunistycznego podziemia, Warszawa 2005, s. 96.

${ }^{64}$ AIPN BU, 944/114, Protokół przesłuchania płk Józefa Rybickiego, Warszawa, 17 VII 1946 r., k. 104.

${ }^{65}$ AIPN BU, 944/114, Protokół przesłuchania płk Józefa Rybickiego, Warszawa, 4 II 1946 r., k. 42 v; ibidem, Zeznania Józefa Rybickiego na procesie, 16 I 1947 r., k. 550.

${ }^{66}$ G. Motyka, R. Wnuk, Pany i rezuny..., s. 182. AIPN BU, 944/114, Protokół przesłuchania płk Józefa Rybickiego, Warszawa, 4 II 1946 r., k. 42 v.

${ }^{67}$ AIPN BU, 944/114, Protokół konfrontacji pomiędzy Marianem Gołębiewskim a Józefem Rybickim, Warszawa, 15 VII 1946 r., k. 101.

${ }^{68}$ AIPN BU, 944/114, Protokół przesłuchania Macieja Rybickiego, Warszawa, 4 II 1946 r., k. 43. 
wość tego podkreślit płk. Rzepecki - zeznawał Józef Rybicki ${ }^{69}$. W trakcie procesu I ZG WiN obecni na zebraniu w Łodzi zgodnie twierdzili, że zapadła wówczas decyzja mówiąca o zakazie współpracy z UPA ${ }^{70}$. Józef Rybicki tłumaczył, co nimi kierowało: [...] nie jesteśmy organizacja, która się może wiązać z zewnętrznymi czynnikami, prowadzić politykę zagraniczna, dodałem ze strony uczuciowej, że kto był w powstaniu warszawskim, styszał o Zieleniaku, to mu wystarczy $[\ldots]^{71}$. Temat ten pojawił się ponownie na kolejnym zjeździe 23 listopada 1945 r., już po aresztowaniu Rzepeckiego. Według wyjaśnień Rybickiego składanych podczas procesu potwierdził on poprzednie ustalenia, natomiast $\mathrm{w}$ zeznaniach ze śledztwa podawał, że nie podjęto wówczas żadnych wiążących decyzji, ponieważ omawiano pilniejsze sprawy $^{72}$.

Gołębiewski jako jedyny w trakcie śledztwa zeznawał coś zupełnie innego. Utrzymywał, że choć dowództwo WiN odnosiło się niechętnie do porozumień, to nigdy nie wydało definitywnego zakazu współpracy ${ }^{73}$. $\mathrm{Na}$ wspótprace terenowa w naszym okręgu org. WiN z org. UPA - twierdził - posiadaliśmy całkowita sankcję szefa obszaru centralnego - "Macieja" przez to, że nie zabraniat nam jej wiedzac szczegółowo o rozmiarach tej wspótpracy $z$ raportów naszych $i$ załączników do listopada $i$ grudnia $1945 r r^{74}$. W trakcie innego przesłuchania Gołębiewski również podkreślał, że jeszcze w grudniu 1945 r. „Maciej” polecił mu nie przerywać współpracy, nie poszerzać, tylko utrzymać na dotychczasowym poziomie ${ }^{75}$. Wersję, której trzymał się w czasie śledztwa, zmienił dopiero na procesie przeciwko przywódcom I ZG WiN i potwierdził, że otrzymał od „Macieja” polecenie całkowitego zaprzestania kontaktów z Ukraińcami ${ }^{76}$. Po latach również przyznał, że rzeczywiście Rybicki kategorycznie zabraniał kontaktów z UPA ${ }^{77}$. Jak zatem tłumaczyć te rozbieżności? Jeśli zakaz współpracy zapadł na szczeblu centralnym, oznaczało to, że Gołębiewski mu się nie podporządkował,

\footnotetext{
${ }^{69}$ Ibidem.

${ }^{70}$ Taką wersję utrzymywali członkowie I ZG WiN na procesie. Po latach tak samo do tej sprawy odnosił się Jan Rzepecki. SPP, B.I.35, Relacja Jana Rzepeckiego, k. 298.

${ }^{71}$ AIPN BU, 944/122, Zeznania J. Rybickiego na rozprawie, 17 I 1947 r., k. 569-570.

${ }^{72}$ AIPN BU, 944/122, Wyjaśnienia Józefa Rybickiego składane na procesie, 16 I 1947 r., k. 570. AIPN BU, 944/114, Protokół przesłuchania Macieja Rybickiego, Warszawa, 4 II 1946 r., k. 43 v.

${ }^{73}$ G. Motyka, R. Wnuk, Pany i rezuny..., s. 182.

${ }^{74}$ AIPN BU, 944/114, Protokół przesłuchania Mariana Gołębiewskiego, Warszawa, 13 V 1946 r., k. 264.

${ }^{75}$ AIPN BU, 944/114, Protokół przesłuchania Mariana Gołębiewskiego, Warszawa, 25 IV 1946 r., k. 231 v.

${ }^{76}$ AIPN BU, 944/122, Wyjaśnienia składane przez Mariana Gołębiewskiego na procesie, 16 I 1947 r., k. 524.

${ }^{77}$ G. Motyka, R. Wnuk, Pany i rezuny..., s. 183.
} 
a w więzieniu starał się usprawiedliwić swoją niesubordynację i działalność na własną rękę. Jednocześnie należy wziąć pod uwagę fakt, że jego zeznania były efektem stosowanych metod śledczych i niektóre $z$ nich zostały wymuszone ${ }^{78}$. Wiele na to wskazuje, że właśnie fakt współpracy DSZ-WiN Okręgu Lublin z OUN-B i UPA przesądził o tym, że kpt. Mariana Gołębiewskiego włączono do procesu pokazowego przeciwko członkom i twórcom I ZG WiN. Zachowane źródła świadczą o tym, że w śledztwie, a później na procesie władze komunistyczne chciały udowodnić, iż kontakty z podziemiem ukraińskim nawiązano na polecenie przywódców poakowskiej konspiracji. Tak można interpretować wypowiedź prokuratora płk. Henryka Holdera, gdy mówił, że: Paktowanie Stera z Upowcami - to nie wybryk terenowego opryszka ${ }^{79}$. Słowa te wyraźnie sugerowały, że rozmowy podejmowane przez Mariana Gołębiewskiego miały być $\mathrm{w}$ rzeczywistości rezultatem instrukcji płynących od przełożonych $^{80}$. Ale czy można całkowicie odrzucić i taką tezę, że choć I ZG WiN odrzucił możliwość współpracy z OUN, to utrzymał zawieszenie broni, natomiast $\mathrm{w}$ śledztwie $\mathrm{w}$ interesie oskarżonych było mówienie o zakazie współpracy?

Otóż dopiero jesienią 1945 r. kpt. „Ster” polecił kpt. Janowi Turowskiemu "Norbertowi", komendantowi Obwodu Tomaszów Lubelski WiN, aby poinformował stronę ukraińską o stanowisku Komendy Głównej WiN ${ }^{81}$. Według „Norberta” nastąpiło to w listopadzie

${ }^{78}$ Wobec przywódców I KG WiN nie stosowano przemocy fizycznej. Natomiast jeśli chodzi o osoby takie, jak Gołębiewski czy kpt. Henryk Żuk, które włączono dla celów propagandowych do procesu, reguły te nie obowiązywały.

${ }^{79}$ AIPN BU, 944/123, Stenogram procesu, 25 I 1947 r., k. 135.

${ }^{80}$ Co więcej, oficer śledczy MBP por. Wiktor Leszkowicz w sporządzonym latem 1946 r. sprawozdaniu na temat śledztwa m. in. pisał: Gołębiewski zeznaje, że okręg lubelski org. WiN na polecenie Kom. Obszaru Centralnego "Macieja” nawiązał łaczność z UPA celem wspólnej walki. AIPN BU, 0259/106, t. 7, Sprawozdanie z przeprowadzonego śledztwa KG orga. WiN, Warszawa, 12 VII 1946 r., k. 7. Tymczasem żadne protokoły przesłuchań Mariana Gołębiewskiego tego nie potwierdziły. Antoni B. Szcześniak i Wiesław Z. Szota pisząc Drogę doniką... na podstawie materiału ze śledztwa nie byli w stanie na kartach książki jednoznacznie odpowiedzieć, czy inicjatywa spotkań wyszła ze strony dowódców terenowych, czy "góry" organizacji DSZ i WiN. A. B. Szcześniak, W. Z. Szota, Droga donikąd..., s. 348-349.

${ }^{81}$ Tymczasem Ukraińcy po spotkaniu 21 maja 1945 r. w Żarach oczekiwali na odpowiedź ze strony polskiego podziemia. Płk Jurij Łopatyńskyj „Szejk” kilkakrotnie próbował skontaktować się z Polakami, aby uzyskać informację o stanowisku Komendy Głównej. To właśnie on zaproponował wysłanie do Galicji Wschodniej kilku- lub kilkunastoosobowego patrolu złożonego z żołnierzy WiN, który na własne oczy zobaczyłby, jakie warunki panują na tych terenach, chcąc tym samym przełamać polską nieufność. Gdy to się nie udało, jesienią 1945 r. przeszedł do Zachodnich Niemiec. G. Motyka, R. Wnuk, Pany i rezuny..., s. 92-93. 
1945 r. ${ }^{82}$, co mogłoby wskazywać, że przekazywał on decyzję podjętą na zjeździe Zarządu Głównego WiN w Łodzi 4 listopada 1945 r. „Norbert” spotkał się z przedstawicielami UPA gdzieś w okolicach wioski Łówcza w powiecie lubaczowskim ${ }^{83}$. Jeśli wierzyć jego zeznaniom, to poinformował przedstawicieli UPA, że władze kierownicze Zrzeszenia nie podejmą bliższej współpracy, ale są zainteresowane utrzymaniem zawieszenia broni ${ }^{84}$. W świetle przedstawionych faktów możliwe są dwie interpretacje. Zgodnie z pierwszą jeżeli w Łodzi zapadła decyzja o zakazie współpracy, wówczas oznaczałoby to, że Gołębiewski samowolnie przekazał inną wersję, dążąc jednocześnie do zmiany tej decyzji. Zgodnie z drugą - takie rzeczywiście było stanowisko Komendy Głównej. Jan Turowski otrzymał od Ukraińców informację o sytuacji w ZSRR. Przedstawiciele UPA prosili o pomoc sanitarną dla ich organizacji, na którą "Ster" miał wyrazić zgodę 85 .

Mimo to Marian Gołębiewski po aresztowaniu płk. Rzepeckiego jesienią 1945 r. jeszcze raz zwrócił się do „Macieja” o rozważenie sprawy ukraińskiej. Przedstawił mu wówczas propozycję strony ukraińskiej wysłania patrolu do Galicji Wschodniej oraz przerzucenia delegatów za granicę $^{86}$. Gołębiewski wspominał, że przygotowywał już do wysłania za granicę na tereny Ukrainy sześciu patroli, których część miała tam pozostać w charakterze łączników. Operacja była planowana na wiosnę 1946 r. ${ }^{87}$ Konsultował ten pomysł z ówczesnym Komendantem Okręgu, który ponoć odniósł się do niego sceptycznie ${ }^{88}$. Józef Rybicki miał jeszcze raz rozważyć całą sprawę, ale jednocześnie postanowił odwołać „Stera” ze stanowiska ${ }^{89}$. Na ostatnim spotkaniu organizacyjnym, przed aresztowaniem Rybickiego w Warszawie w grudniu 1945 r., "Ster" referował mu bieżący stan w kwestii ukraińskiej. Liczył na to, że uda mu się przekonać kierownictwo Zrzeszenia WiN, aby zajęło pozytywne stanowisko w tej sprawie. k. 39.

${ }^{82}$ AIPN Lu, 17/978, Protokół przesłuchania Jana Turowskiego, Warszawa, 7 X 1946 r.,

${ }^{83}$ Towarzyszył mu komendant sąsiadującego z pow. lubaczowskim rejonu V Obwodu Tomaszów Marian Warda „Polakowski” z kilkuosobową osłoną z oddziału Karola Kosteckiego „Kostka”.

${ }^{84}$ AIPN Lu, 17/978, Protokół przesłuchania Jana Turowskiego, Warszawa, 7 X 1946 r., k. 39.

${ }^{85}$ AIPN BU, 944/114, Protokół przesłuchania Mariana Gołębiewskiego, Warszawa, 13 V 1946 r., k. k. 264 v.

${ }^{86}$ Ibidem.

${ }^{87}$ AOiR,WP”, Artykuł Mariana Gołębiewskiego Uwagi do artykułu „Wspólna walka" c.d. z 3 VIII 1984 r., b. p.

${ }^{88}$ AIPN BU, 944/114, Protokół przesłuchania Mariana Gołębiewskiego, Warszawa, 26 I 1946 r., k. 127 v.

${ }^{89}$ G. Motyka, R. Wnuk, Pany i rezuny..., s. 182. 
Temat ten miał być rzekomo omawiany jeszcze w styczniu 1946 r. Niewątpliwie dalsze czynności uzależniano od stosunku Ukraińców do wschodnich terenów II RP ${ }^{90}$. Przynajmniej tak interpretował to "Ster"91. Nie ulega kwestii, że Gołębiewskiemu bardzo zależało na kontynuowaniu zapoczątkowanej w maju 1945 r. współpracy i za wszelką cenę dążył do przekonania sceptycznie nastawionego "Macieja”92. Zdaniem Józefa Rybickiego głównym motorem postępowania "Stera” była obawa, że zerwanie współpracy spowoduje powrót do sytuacji sprzed porozumienia ${ }^{93}$.

Działania podejmowane przez Mariana Gołębiewskiego dowodza, że nie zaakceptował stanowiska ZG WiN i w dalszym ciagu próbował wpłynąć na zmianę decyzji. W związku z tym w połowie grudnia $1945 \mathrm{r}$. spotkał się w Warszawie jeszcze z płk. Wincentym Kwiecińskim, który pełnił wówczas funkcję szefa wywiadu i jednocześnie zastępcy Józefa Rybickiego „Macieja”. Zabiegał o poparcie za jego pośrednictwem sprawy ukraińskiej. Ponadto przekazał mu informacje wywiadowcze otrzymane od Ukraińców i przekonywał: Jeśli chcemy walczyć o niepodległość, to [...] jedynym sojusznikiem moga być Ukraińcy ${ }^{94}$. Kwieciński ponoć obiecał poprzeć tę sprawę u „Macieja"95.

Zawieszenie broni miedzy poakowskim podziemiem a ukraińską partyzantką w południowo-wschodniej Lubelszczyźnie i Podlasiu przyczyniło się do przerwania fali przemocy, której ofiarą padała ludność polska i ukraińska zamieszkała na terenach mieszanych etnicznie. Zostało ono zaakceptowane przez kierownictwo Delegatury Sił Zbrojnych jedynie $\mathrm{w}$ formie paktu o nieagresji. Przywódcy polskiej konspiracji od początku godzili się na zawieszenie broni, choć jednocześnie nie chcieli zawierania umów i nie widzieli możliwości bliższej współpracy i współdziałania z OUN-UPA czy reprezentowania sprawy ukraińskiej na forum międzynarodowym w ówczesnej sytuacji politycznej. Niewątpliwie na stosunek przywódców polskiej konspiracji do porozumienia na Lubelszczyźnie miało wpływ przejście z konspiracji wojskowej do cywilnej. Mimo tego porozumienie zawarte 21 maja 1945 r. przetrwało tu do akcji „Wisła” i na tle trudnych relacji polsko-ukraińskch pierwszej połowy XX wieku stanowiło pozytywny element.

\footnotetext{
${ }^{90}$ AIPN BU, 944/114, Protokół konfrontacji pomiędzy Marianem Gołębiewskim i Józefem Rybickim, Warszawa, 15 VII 1946 r., k. 101.

${ }^{91}$ AIPN BU, 944/114, Protokół przesłuchania Mariana Gołębiewskiego, Warszawa, 13 V 1946 r., k. 269.

${ }^{92}$ M. Zajączkowski, Działalność Organizacji Ukraińskich..., s. 500.

${ }^{93}$ AIPN BU, 944/122, Zeznania Józefa Rybickiego na procesie, 16 I 1947 r., k. 585.

${ }^{94}$ G. Motyka, R. Wnuk, Pany i rezuny..., s. 183.

${ }_{95}^{5}$ Ibidem; AIPN BU, 944/114, Protokół przesłuchania Mariana Gołębiewskiego, Warszawa, 13 V 1946 r., k. 265.
} 


\section{BIBLIOGRAFIA:}

„Bo mnie tylko wolność interesuje...". Wywiad rzeka z Marianem Gołęiewskim (Nowy Jork, listopad 1988 - czerwiec 1989), oprac. J. Dudek, Lublin 2011.

Chmielarz A., Powstanie i działalność I Zarządu Głównego Zrzeszenia WiN, „Zeszyty Historyczne WiN-u" 2006, nr 25.

Gałęzowski M., Henryk Józewski „Olgierd”, "Zeszyty Historyczne” 2004, z. 150.

Honisz T., Zrzeszenie "Wolność i Niezawistość" [w:] Armia Krajowa. Dramatyczny epilog, red. K. Komorowski, Warszawa 1994.

Iwaneczko D., „Przypadek czy przeznaczenie?”. Karol Kazimierz Kostecki „Kostek” (1917-1998), Rzeszów 2013.

Kamiński Ł., Próby porozumienia polskiego i ukraińskiego podziemia w latach 1945-1946. Dokumenty, „Wrocławskie Studia Wschodnie” 1999, nr 3.

Kopiński J., Konspiracja akowska i poakowska na terenie Inspektoratu Rejonowego „Radzyń Podlaski" w latach 1944-1956, Biała Podlaska 1998.

Lipiński P., Raport Rzepeckiego. Historia twórcy antykomunistycznego podziemia, Warszawa 2005.

Moszkowicz M., Gdzie w maju 1945 r. kierownictwo Inspektoratu AK-DSZ Zamość prowadziło rozmowy i zawarło porozumienie z OUN-B i UPA? , "Cieszanowskie Zeszyty Regionalne” 2012, z. 5.

Motyka G., Cień Kłyma Sawura. Polsko-ukraiński konflikt pamięci, Gdańsk 2013.

Motyka G., Tak byto w Bieszczadach. Walki polsko-ukraińskie 1943-1948, Warszawa 1999.

Motyka G., Ukrainska partyzantka 1942-1960, Warszawa 2006.

Motyka G., Wnuk R., Pany i rezuny. Wspótpraca AK-WiN i UPA 1945-1947, Warszawa 1997.

Motyka G., Wnuk R., Pany i rezuny na emigracji. Próby porozumienia polsko-ukraińskiego na Zachodzie 1945-1950, „Więź” 2000, nr 9.

Ostasz G., Okręg Rzeszowski Zrzeszenia „Wolność i Niezawisłość”. Model konspiracji, struktura, dzieje, Rzeszów 2006.

Szcześniak A. B., Szota W. Z., Droga donikąd. Działalność organizacji Ukraińskich nacjonalistów i jej likwidacja w Polsce, Warszawa 1973.

Sztendera J., W poszukiwaniu porozumienia (Podziemie ukrainskie i polskie w latach 1945-1947. Wspótpraca pomiędzy UPA $i$ WiN), „Zeszyty Historyczne” 1985, nr 71.

Wnuk R., Lubelski Okręg AK, DSZ i WiN 1944-1947, Warszawa 2000.

Wnuk R., Konspiracja akowska i poakowska na Zamojszczyźnie od lipca 1945 do 1956 roku, Lublin 1992.

Zajączkowski M., Drogi do porozumienia między polskim i ukraińskim podziemiem niepodległościowym w latach 1945-1947 [w:] Od zniewolenia do wolności. Studia historyczne, red, A.F. Baran, Warszawa - Białystok 2009.

Zajączkowski M., Działalność Organizacji Ukraińskich Nacjonalistów i Ukraińskiej Powstańczej Armii na Lubelszczyźnie 1939-1947, ISP PAN, (mps rozprawy doktorskiej).

Zajączkowski M., Ukraińskie podziemie na Lubelszczyźnie w okresie okupacji niemieckiej 19391944, Lublin-Warszawa 2015. 


\section{ABSTRACT:}

The paper discusses the attitude of the leadership of the Delegacy of Armed Forces at Home (DSZ) and the „Freedom and Independence” organization (WiN) towards an agreement reached on 21 May 1945 near Ruda Różaniecka between former units of the Polish Home Army and the Organization of Ukrainian Nationalists „Bandera” (OUN-B) and the Ukrainian Insurgent Army (UPA). The agreement undoubtedly led to the cessation of hostilities that had been going on in the Lublin Region since spring 1944. Making use of previously unknown records, the author proves that contrary to what numerous testimonies of that period say, the DSZ leaders accepted this local non-aggression pact. Although the leadership of the Delegacy of Armed Forces at Home approved of the armistice from the very beginning, they did not, however, want to sign any treaties, closer cooperate with OUN-B and UPA or promote the Ukrainian cause on the international agenda. Following the establishment of the "Freedom and Independence" organization which advocated a model of civilian conspiracy and dissociated itself from the Polish Government in Exile, both the Polish and Ukrainian side began to show less and less interest in cooperation.

Key words: The Delegacy of Armed Forces at Home (DSZ), „Freedom and Independence " organization, Polish-Ukrainian agreement, Lublin region, political trial of „Freedom and Independence" organization

\section{NOTA O AUTORZE:}

Justyna Dudek (ur. 1982) - historyk, absolwentka Katolickiego Uniwersytetu Lubelskiego Jana Pawła II, doktor nauk humanistycznych, pracownik Referatu Badań Naukowych OBEP IPN w Lublinie. Zajmuje się różnymi aspektami działalności polskiego podziemia niepodległościowego po 1944 r., e-mail: justyna.dudek@ipn.gov.pl 